Portland State University

PDXScholar

Geography Faculty Publications and

Presentations

Geography

$3-2020$

\title{
Legal Geographies and Political Ecologies of Water Allocation in Maui, Hawai'i
}

\author{
Alida Cantor \\ Portland State University, acantor@pdx.edu \\ Kelly Kay \\ University of California, Los Angeles \\ Chris Knudson \\ University of Hawaii, Hilo
}

Follow this and additional works at: https://pdxscholar.library.pdx.edu/geog_fac

Part of the Physical and Environmental Geography Commons

Let us know how access to this document benefits you.

\section{Citation Details}

Cantor, A., Kay, K., \& Knudson, C. (2020). Legal geographies and political ecologies of water allocation in Maui, Hawai'i. Geoforum.

This Post-Print is brought to you for free and open access. It has been accepted for inclusion in Geography Faculty Publications and Presentations by an authorized administrator of PDXScholar. Please contact us if we can make this document more accessible: pdxscholar@pdx.edu. 


\section{Legal geographies and political ecologies of water allocation in Maui, Hawai' $i$ \\ Alida Cantor, ${ }^{1}$ Kelly Kay, ${ }^{2}$ and Chris Knudson ${ }^{3}$ \\ Contact information: Alida Cantor, acantor@pdx.edu}

Keywords: Legal geography; political ecology; water governance; Hawai‘i; hybridity; legal pluralism

Abstract: Throughout the Hawaiian Islands, sugar plantations have controlled a large proportion of water resources for over a century, often leaving little water in streams to support ecosystems or Native Hawaiian cultural and agricultural practices. Recently, in Maui, Hawai' $i$, community activists and lawyers representing Native Hawaiian and environmental interests have successfully reclaimed water resources for instream flow utilizing legal processes and tools such as Hawai'i's public trust doctrine, which has plural roots in both Hawaiian and Western legal traditions. In this paper, we use qualitative fieldwork, including interviews, participant observation, and archival data collection, to explore two recent and ongoing legal cases around water allocation in Maui: Nā Wai 'Ehā and East Maui. The research uses legal geography and political ecology to examine the use of the public trust doctrine in challenging water allocation practices in Maui, specifically focusing on the concepts of legal pluralism and socioenvironmental hybridity. We examine the ways in which plural legal processes and precedents have developed and combined in place-specific ways, and connect legal pluralism with ideas of hybridity from nature-society geography. In keeping with the goals of political ecology, the paper examines legal processes and socioenvironmental change as inextricable and power-laden. We demonstrate that the intersection of legal geography with political ecology can contribute a stronger understanding of the context-specific dynamics of socioenvironmental change.

\footnotetext{
${ }^{1}$ Portland State University, Portland, OR, USA

2 University of California Los Angeles, CA, USA

${ }^{3}$ University of Hawai'i at Hilo, HI, USA
} 


\section{Introduction}

Water holds a deeply important role in Hawaiian culture and tradition. The Hawaiian word for water, wai, is directly related to the words for wealth—waiwai-and law—kanawai. Throughout the Hawaiian Islands, sugar plantations have controlled a large proportion of freshwater and groundwater resources for over a century, often leaving little water in streams to support ecosystems or Native Hawaiian agriculture and cultural practices. (MacLennan, 2014; Wilcox, 1997). On the island of Maui, Hawai'i, in recent years, community activists and lawyers representing Native Hawaiian and environmental interests have successfully reclaimed water resources (Sproat, 2011; Sylva, 2007). Utilizing legal tools such as the public trust doctrine, which has roots in both Hawaiian and Western legal traditions, these coalitions have successfully restored streamflow to support aquatic resources and renew traditional Hawaiian practices such as kalo (Hawaiian taro) farming.

The legal contestations around water resources have taken place in a broader context of a historically strong yet declining commercial sugar industry (MacLennan, 2014). Throughout its global history, the plantation sugar industry has had extensive influence not only on water resource use, but also on politics, economics, and social structures (Mintz, 1986), including in Hawai'i (Cooper and Daws, 1990; MacLennan, 2014). In recent decades, sugar production has declined in Hawai' $i$ as other locations around the world have become cheaper sites of production (MacLennan, 2014). The last commercial harvest of sugar on Maui took place in late 2016, leaving the island's plantation agricultural landscape — and water resource allocation practices_facing significant changes. However, the physical, legal, and political infrastructures of water 
management developed in the era of sugar remain dominant forces in Hawai'i (MacLennan, 2014).

In this paper, we explore recent and ongoing legal contestations around Maui's water allocation to highlight the relationships between place and law. Legal geography examines the coproduction of law and place/space, focusing on the interactions between legal, spatial, and social processes (Bennett and Layard, 2015; Braverman et al., 2014). When combined with political ecology, legal geography can facilitate an analysis of the co-constitutive relationships between formal legal processes and socioenvironmental politics and change (Andrews and McCarthy, 2014). Since Andrews and McCarthy's call in 2014 to link legal geography and political ecology more explicitly, a plethora of recent scholarship has demonstrated the utility of examining formalized legal and policy processes, power dynamics, and environmental change in relation to one another (Cantor, 2016; Delaney, 2017; Gillespie, 2018; Kay, 2016; O’Donnell, 2019; Salgo and Gillespie, 2018). Here, we examine contemporary relationships between water allocation and law, focusing on concepts of legal plurality and socioenvironmental hybridity. In keeping with the goals of political ecology, we examine environmental change as a power-laden process. We focus on how laws are interpreted, challenged, and enacted in ways that can maintain but also challenge the power dynamics imbricated in socioenvironmental arrangements.

We begin with a review of the literatures on legal geography, legal pluralism, and hybrid geographies. We next describe our methodology and contextualize our study by describing Hawaiian water resources and water rights, then present two case studies: Nā Wai 'Ehā and East Maui. Using the cases, we first discuss the evolution of a place-based public trust doctrine, 
highlighting elements of plurality and hybridity, and second examine the power dynamics that impact implementation of legal processes and accompanying socioecological outcomes.

\section{Legal geography, political ecology, pluralism, and hybridity}

While nature was once an understudied facet of legal geographical scholarship (Delaney, 2003), there has been a recent renaissance in geographies seeking to develop a stronger critical understanding of the interactions between legal processes and more-than-human environments (as noted by Delaney, 2017; Robinson and Graham, 2018). Bolstered by Andrews and McCarthy's (2014) call to avoid overlooking the important formalized legal and policy processes that are frequently involved in environmental change, scholars have engaged tools of legal geography and political ecology in conjunction with one another. The emerging body of work in the nexus of legal geography and political ecology has emphasized several themes, including how socioecological processes and property rights regimes are contested through legal means (Cantor, 2016; Gillespie, 2016; O’Donnell, 2019; Robertson, 2015); how different state and nonstate actors frame and experience legal power struggles around environmental issues (Brown et al., 2019; Salgo and Gillespie, 2018; Turton, 2015); and how political economy comes to bear on environmental law and management (Andrews and McCarthy, 2014; Jepson, 2012; Kay, 2016; Quastel, 2017).

In this paper, we build upon this growing area of scholarship. Here, we review literature on legal pluralism (a concept primarily drawn from legal geography) as well as nature-society hybridity (a concept from nature-society geography that has been taken up within political ecology), proposing the utility of a tighter connection between the two bodies of scholarship. 


\subsection{Legal pluralism and legal geography}

Within legal geography and socio-legal studies, the study of legal pluralism recognizes that many societies have competing and overlapping legal traditions. In the 1980s, scholarship in the area of law and society introduced the concept of legal pluralism to challenge the idea that law is a "single, unified and exclusive hierarchical normative ordering depending from the power of the state" (Griffiths, 1986; p. 4). John Griffiths describes legal pluralism as "the presence in a social field of more than one legal order" (1986; p. 1). Building on this concept, legal scholars have demonstrated that through processes such as colonialism (Merry, 1988; Randeria, 2006), religious traditions (Yilmaz, 2016), and globalization (Rajagopal, 2005), places are often governed by multiple systems of law, and that legal pluralism may even be the norm rather than the exception (Merry, 1988). Dynamics between multiple coexisting legal systems may vary depending upon the specific context; these different systems may at times "support, complement, ignore, or frustrate one another" (Griffiths, 1986, p. 1). This area of scholarship has built a stronger understanding of the breadth and diversity of legal systems and other normative orders, and the types of interactions between them (Tamanaha, 2008, 1993; von Benda-Beckmann, 2002).

The concept of pluralism has been taken up by legal geographers interested in spatial dimensions of how legal regimes overlap and interact (Robinson and Graham, 2018). Combining a concern for law and place with empirical research methods and detailed case studies, geographers have leveraged the idea of legal pluralism to examine a variety of themes including humanenvironment relationships in numerous contexts. For example, legal pluralism has been a useful 
tool for understanding overlapping land use regimes impacting management (Gillespie, 2011); and in a recent special issue focusing on legal pluralism and geography (Robinson and Graham, 2018), geographers used legal pluralism to study a diverse range of environmental issues including legal personhood for rivers (Charpleix, 2018), layered legal and regulatory arrangements shaping wetland conservation (Gillespie, 2018), and the agency of place in legal orders (Bartel, 2018).

When applied to resource management conflicts involving colonialism and Indigenous peoples' claims to natural resources, it becomes clear that legal pluralism does not guarantee a smooth, equal, or unproblematic blend of legal traditions. Indigenous and Eurocentric/colonial resource management systems are frequently based in fundamentally incompatible ontologies (Howitt and Suchet-Pearson, 2006), rendering a seamless blend impossible. Recent scholarship on legal pluralism in postcolonial contexts emphasizes the contestations that can arise between Indigenous laws and state-imposed legal regimes (Charpleix, 2018; Gillespie, 2018). Several scholars have discussed this issue in relation to water management: for example, as Sue Jackson describes, attempts to recognize Aboriginal water management regimes as legitimate have butted up against historic legacies of inequality and discrimination (Hartwig et al., 2018), and control of water has been a critical tool in displacement and dispossession of Indigenous people in a variety of settings (Berry and Jackson, 2018; Jackson, 2018). Scholars who have examined legal pluralism in relation to water rights, such as Rutgerd Boelens and Margreet Zwarteveen, describe the uneven power relationships and intense conflicts that can accompany plural legal systems of water governance (Boelens and Vos, 2014; Roth et al., 2015; Vos et al., 2006; Zwarteveen et al., 2005). 
Legal pluralism has a long and important tradition in Hawai'i. Hawaiian legal and cultural scholar and geographer Kamanamaikalani Beamer explains that the history of formally codified Hawaiian law and the emergence and extension of Western law arose in tandem (Beamer, 2014). Beamer describes two of the most important shifts in Hawaiian law—-the Great Māhele and the Kuleana Acts_as "hybrid laws" $(2014,151)$. For example, the Kuleana Acts on the one hand created Western forms of private property, but simultaneously codified and protected longstanding Hawaiian forms of property in ways that incorporated their unique socio-natural character (MacLennan, 2014). In 1978, Hawai'i’s Constitutional Convention paved the way for increased recognition of Native Hawaiian rights, thereby solidifying legal pluralism as a guiding principle of Hawaiian state law (e.g. Conway 2008). Legal pluralism is an ongoing process: for example, Hawaiian customary coastal management practices have been integrated into contemporary state fishery management law (Vaughan et al., 2017).

\subsection{Connecting socionatural hybridity and legal pluralism}

Legal geography focuses on law and society as co-produced (Bennett and Layard, 2015), rather than as separate binary realms that interact. Hybrid geography similarly focuses on the coproduction and intra-action of human and nonhuman elements. Conceptions of hybridity and hybrid geographies stem largely from feminist as well as critical nature-society geography (e.g., Haraway, 1991; Lave, 2015; Swyngedouw, 1999; Whatmore, 2002). As developed by Sarah Whatmore, 'hybrid geographies' examine the inextricable linkages between the oft-separated human/nonhuman and social/material realms, critically examining and challenging binary 
constructions (Whatmore, 2002). Using concepts of actor-network theory, hybrids are understood not as a "mixture of two pure forms" (Latour 1993, 77-78), but as co-produced through interaction - or intra-action, as Karen Barad proposes, emphasizing the inextricability of such entanglements (Barad, 2007). Critical geographers have used the concept of hybridity to move past the notion of separate but co-existing realms of human and nonhuman (Whatmore, 2002, 1999), while also noting that co-produced socionatural assemblages are frequently laden with power inequities (Cantor et al., 2018; Rocheleau and Roth, 2007; Swyngedouw, 1999). Importantly, Indigenous scholars such as Kim TallBear have emphasized that these seemingly new calls to move beyond human-nonhuman binaries frequently echo much older Indigenous worldviews that have long understand nonhuman life as vibrant and alive (TallBear, 2017).

Water, and water governance, in particular, have been conceptualized by geographers as powerladen hybrids. For example, the concept of the hydro-social cycle integrates physical, social, and political dimensions of water infrastructure and governance (Boelens et al., 2016; Linton and Budds, 2014; Swyngedouw, 2009, 1999). The hydro-social system is hybrid in that it emphasizes internal relations of co-constitution, rather than external relations between separate realms (Linton and Budds, 2014). Concepts of hybridity and actor-network theory have been applied to studies of irrigation systems, water infrastructure, and water governance around the world (e.g. Berry, 2014; Birkenholtz, 2009; French, 2019; Meehan, 2014; Sneddon, 2003). Incorporating socionatural hybridity into legal pluralism is particularly important when considering Indigenous systems of water resource management, which may not make such sharp distinctions between human and nonhuman actors (Martin et al., 2018). For example, as recent cases involving legal personhood for nonhuman nature illustrate, plural legal systems may include different and 
contradictory views of what constitutes a person (Cano Pecharroman, 2018; Martin et al., 2018). Water governance practices that view water as abstracted and static are frequently fundamentally at odds with Indigenous approaches to water resources that are relational (Curran, 2019).

In this paper, we build upon ideas of legal pluralism by also incorporating hybridity, which focuses on the deeply imbricated nature of human and more-than-human worlds. That is, legal pluralism can be extended and mixed with concepts of nature-society hybridity to understand legal processes as more-than-human in many contexts (Jeffrey and Jakala, 2014), and the "society" that legal scholars see as co-produced with law is also co-produced with non-humans (Delaney, 2017, 2003). Most work on legal pluralism focuses on the co-existence of multiple human legal systems. Here, we argue that combining concepts of legal pluralism with ideas of socionatural hybridity can add to a deeper geographic understanding of socio-legal relationships.

\section{Methods}

Political ecology is often characterized by its strong empirical grounding (Robbins, 2011). Similarly, whereas traditional legal scholarship relies upon textual analysis, legal geography research draws upon empirical field methods and contextual analysis in addition to textual analysis of legal decisions and documents (Bennett and Layard, 2015; Braverman, 2014). The application of political ecology field methods to legal studies contributes a place-specific understanding of socioenvironmental contexts and power dynamics; examines the multiple ways in which law may be interpreted by different actors; and focuses on the material impacts of law and legal processes. 
In keeping with empirical geographic methods, our research is based in qualitative fieldwork conducted in Maui and Honolulu from 2017-2019. We conducted semi-structured interviews with 46 people, including community activists, lawyers, government employees, nonprofit members, former sugar industry employees, kalo farmers, Native Hawaiian community advocates, plaintiffs, and other key informants involved in the water rights cases. Some of the 46 individuals were interviewed more than once, and while most interviews were individual, occasionally two or three people were interviewed together. For confidentiality, when interviewees are quoted in this paper they are described in broad terms and their specific affiliations are not noted.

Table 1: Key informant interviewees

\begin{tabular}{|l|l|}
\hline Category of key informant* & $\begin{array}{l}\text { Number of } \\
\text { interviewees }\end{array}$ \\
\hline $\begin{array}{l}\text { Community activists and advocates (including Native Hawaiian advocates, } \\
\text { kalo farmers, environmental advocates, and plaintiffs in water rights cases) }\end{array}$ & 19 \\
\hline Nonprofit representatives & 11 \\
\hline Government agency employees & 9 \\
\hline Attorneys & 5 \\
\hline Former sugar industry employees & 2 \\
\hline Total & $\mathbf{4 6}$ \\
\hline
\end{tabular}

* Some interviewees spanned multiple categories; this table lists primary affiliation only and counts each interviewee only once.

Interviews typically lasted between 1-3 hours, and were either recorded and transcribed or detailed notes were taken. Interviews were coded using Atlas.ti software. Participant observation included site visits (including visiting streams and kalo farms and hiking irrigation ditches), volunteering for environmental and restoration projects, and attending meetings. Archival research included analysis of legal documents (decisions, statements, exhibits, and testimonies related to the two cases), agency reports, archived communications, news articles, and other 
documents retrieved online and in person from the Archival Collections at the University of Hawai'i School of Law Library, the Maui Historical Society and the Bailey House Museum, and the Hawai'i Commission on Water Resource Management.

\section{Maui's water resources and water rights}

\subsection{Water and sugar}

Maui, the second largest of the Hawaiian Islands, features two volcanic mountains joined by a low-lying isthmus (Figure 1). Rain falls unevenly across Maui: the highest rates of rainfall occur in the mountains on the windward sides due to orographic lift of prevailing winds. Maui's two summits each receive over 360 inches of rain per year, while the leeward sides and central plain receive less than 15 inches per year (Giambelluca et al., 2013; Johnson et al., 2014).

Figure 1: Maui's water resource geography, including precipitation, irrigation ditches, ahupua'a boundaries, and sugar cultivation lands. Map by Charles Cody Ross. 


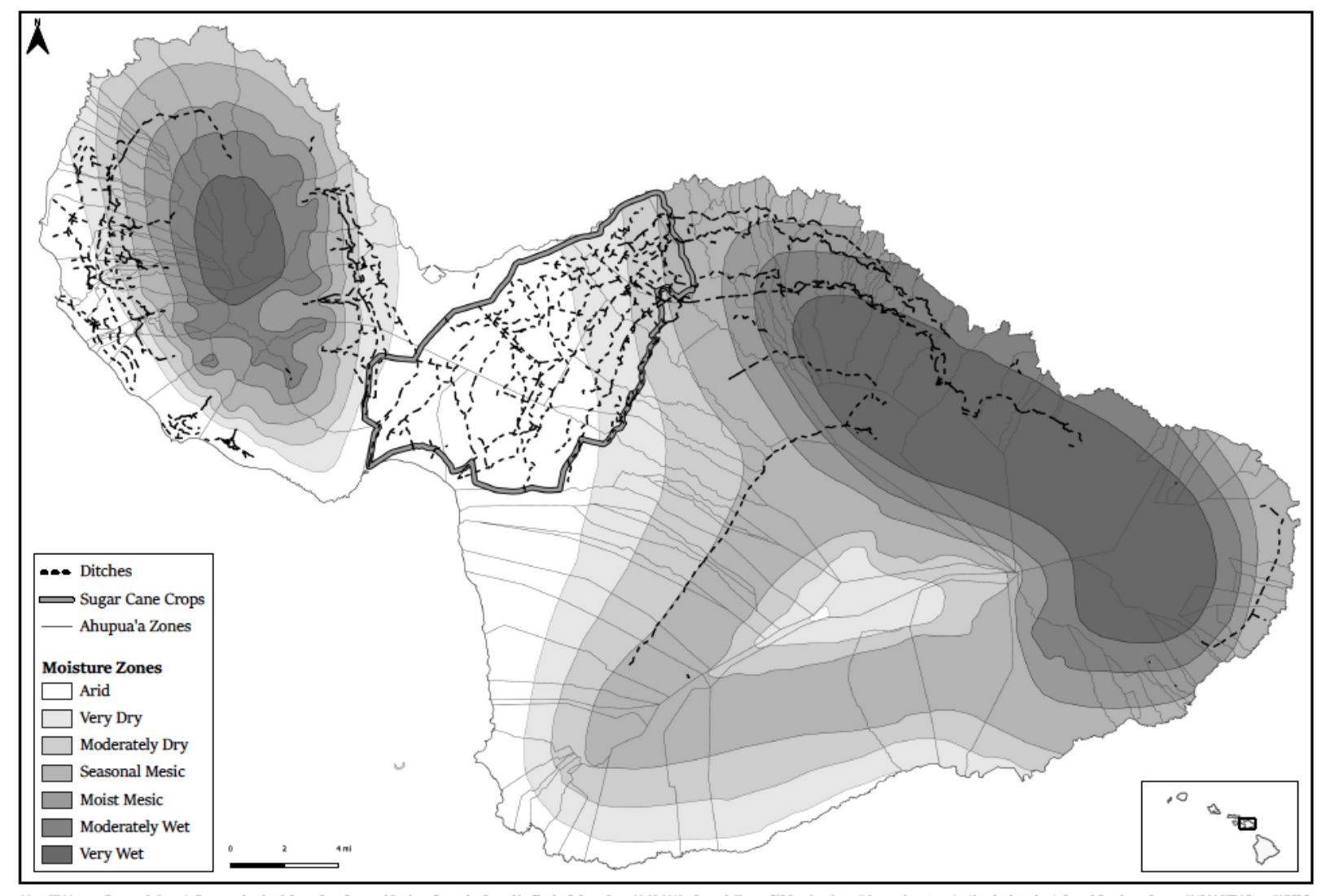

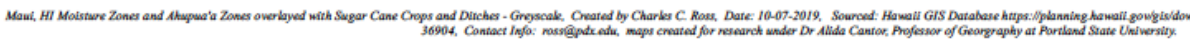

Maui’s many streams represent important ecological, cultural, agricultural, and economic resources. Under the traditional customary Hawaiian resource management system, chiefs known as konohiki administered each ahириа 'a land division and directed water use to benefit the productivity and people associated with that land unit (Fisher, 2015; Miike, 2004; Sproat, 2009). Native Hawaiians have long relied upon streams for kalo cultivation and harvest of fish and shellfish. Kalo is one of the oldest and most culturally important of all food crops in Hawai'i. Among the hundreds of unique varieties grown before European contact in the late $18^{\text {th }}$ century, some were incorporated into Hawaiian rituals and cosmology as offerings to gods (Levin, 2015). 
Throughout Hawai' $i$, including in Maui, the plantation sugar industry was created and controlled by descendants of missionaries and other non-Native Hawaiian businesspeople, beginning in the 1800s and ramping up by the 1840s (MacLennan, 2014). Plantation sugar producers significantly reorganized water resource management throughout Hawai' ${ }^{\prime}$. Commercial sugar production requires large quantities of water: irrigating 100 acres of sugarcane requires one million gallons of water per day (Wilcox, 1997). To solve the geographical mismatch between the areas of abundant water resources (in the streams of the steep mountains) and the flat central plains with abundant sunlight (amenable to plantation-style agriculture but too dry to support sugar), the sugar companies established a network of diversion ditches that brought water to the flat but arid zones of Maui.

While traditional Hawaiian resource management was based around ahириа ' $a$, social-ecological subdivisions of land designating resource management rights and responsibilities (Winter et al., 2018), the plantation sugar diversion ditches cut directly across ahириа 'a (Figure 1). The diversion of water for sugar production harmed both ecosystems and Hawaiian traditional practices. In an example of accumulation by dispossession (Harvey, 2003), the entire streamflow was often diverted, degrading habitat for aquatic life (Gingerich and Wolff, 2005; Oki et al., 2010) and reducing water available for cultivation of stream-fed crops like kalo. In many locations, multiple ditches were dug at high and low elevations to ensure that any groundwater recharge was fully diverted.

Plantation sugar not only impacted water resource allocation, but also brought changes to land and resource management systems more broadly — and was simultaneously enabled by these 
same changes - including a shift away from relational conceptualizations of land and resources toward individual property rights (MacLennan, 2014). The shift to land as private property was formalized through the process of the Great Māhele, which involved the division and titling of Hawaiian land in 1848. During the Great Māhele, both private and communal property were formalized: in addition to establishing private property rights recognized by the Kingdom of Hawai' $i$, the titling process also created official state recognition of Native Hawaiian rights (Beamer, 2014). In terms of water, new types of water rights were developed to support diversion of water out of watersheds for private commercial uses (Sproat, 2009). While Hawai'i's legal structures continued to recognize customary Hawaiian rights to land and water, they simultaneously allowed for widespread prioritization of commercial and plantation water uses and users (Sproat, 2011, 2009; Sproat and Tuteur, 2018).

\subsection{Hawai 'i's public trust doctrine}

The public trust doctrine is a legal principle that holds that certain natural resources are held in trust by the government for the public, and must be managed in the public interest (Blumm and Wood, 2013; Sax, 1970; Wood, 2014). The public trust doctrine is commonly traced back to the Roman Codes of Justinian written in the $6^{\text {th }}$ century. From Roman law, the doctrine passed into English law, then into United States common law, where it has been used to protect resources such as public access to coastlines (Blumm and Wood, 2013; Wood, 2014). Within the United States, interpretation and implementation of the public trust doctrine varies widely from state to state. Some states have affirmed a strong public trust doctrine (primarily to protect public shoreline access), while in other states it has rarely been used. To a limited extent, public trust 
has been applied to other resources: for example, in 1983 California's public trust was applied to water allocation, limiting water diversions from Mono Lake to ensure ecosystem protection (Cantor, 2016; Hart, 1996), and the recent youth-led climate lawsuit Juliana v. United States asserts that the atmosphere should be protected as a public trust resource.

In the Hawaiian context, the public trust doctrine is also deeply rooted in Hawaiian legal and philosophical traditions (Sproat and Tuteur, 2018). Prominent Hawaiian legal scholars such as Kapua'ala Sproat and others have made clear that the public trust doctrine in Hawai ${ }^{\circ} i$ is neither distinctively Western nor entirely Hawaiian, but includes multiple lineages (Beamer, 2014; Sproat, 2011; Sylva, 2007). The Hawai'i Supreme Court has long recognized contemporary Hawaiian water rights as a distinctive "outgrowth of ancient Hawaiian customs" (Sylva 2007, 563, quoting Hawai' $i$ Supreme Court from 1930). The Constitution emphasized the public nature of water and other resources in Hawai' $i$, stating that:

"For the benefit of present and future generations, the State and its political subdivisions shall conserve and protect Hawai 'i's natural beauty and all natural resources, including land, water, air, minerals, and energy sources and shall promote the development and utilization of these resources in a manner consistent with their conservation and in furtherance of the self-sufficiency of the state. All public natural resources are held in trust by the State for the benefit of the people." (Hawai ' $\mathrm{i}$ Constitution, Article XI, Section 1; constitutional amendment added in 1978. Emphasis added.)

To enact these principles of water management as a public trust, the 1978 State Constitution created a new water resources agency responsible for water conservation, quality, and use. In response, the state Water Code was enacted in 1987. The Water Code echoes the Constitution's 
public trust language, declaring that "the people of the State are beneficiaries and have a right to have the waters protected for their use." The Commission on Water Resource Management (the Water Commission) was also established. Today, Hawai'i’s seven-person Water Commission is the decision-making body tasked with interpreting and implementing water resource allocation decisions. The Water Commission, a non-elected body appointed by elected officials, holds broad administrative power to sanction water uses deemed 'reasonable-beneficial.' The Water Commission has broad jurisdiction over water disputes in the state, and parties may bring issues before the Commission through contested case hearings.

The landmark case of Oahu's Waiāhole Ditch (see Berry, 2006; Miike, 2008; Sproat, 2009) put the new Water Commission to the test throughout the 1990s. In the Waiāhole case, Earthjustice and the Native Hawaiian Legal Corporation sought to return water previously used for sugar to support streams and kalo cultivation. The Water Commission proposed dividing the water to support multiple users' interests, but upon appeal, the Hawai'i Supreme Court repeatedly found that the Commission did not adequately protect public trust interests (Sproat, 2009; Sproat and Tuteur, 2018). In the Waiāhole decision, the Hawai'i Supreme Court noted the tricky "dual nature" of water resources: "the Hawai'i Constitution requires the state both to 'protect' natural resources and to promote their 'use and development"' (Supreme Court of Hawai 'i, 2000; III.B.3.b.ii). However, the Supreme Court decision also noted that despite the state's responsibility to ensure water for agriculture and commercial use, "adequate provision shall be made for the protection of traditional and customary Hawaiian rights, the protection and procreation of fish and wildlife, the maintenance of proper ecological balance and scenic 
beauty.... Such objectives are declared to be in the public interest." (Supreme Court of Hawai'i, 2000; III.C.2.c).

The Waiāhole case emphasized the links between traditional and contemporary Hawaiian water management concepts and practices (Berry, 2006). The case also affirmed the Water Commission's responsibility to protect both cultural and ecological uses of Hawai'i’s water resources - and the role of the state Supreme Court as a backstop to ensure the Water Commission indeed fulfilled its public trust responsibility. ${ }^{\mathrm{i}}$ The Supreme Court made it clear that the Water Commission has the difficult task of managing water for diverse purposes and constituencies, but that, ultimately, traditional and customary Hawaiian rights as well as fish and wildlife must be protected.

\section{Case studies: Securing instream flows for Maui's streams}

Here, we describe the cases of Nā Wai 'Ehā and East Maui, two instances of recent conflict over water rights which have leveraged the public trust doctrine. Both have resulted in significant stream restoration in Maui (see Figure 2). The cases are not meant as a comparison; instead they are meant to demonstrate the multiple sites and stories of contestation around water rights and to illustrate the public trust doctrine at work.

Figure 2: Streams restored through the Nā Wai 'Ehā and East Maui cases. Map by Charles Cody Ross. 

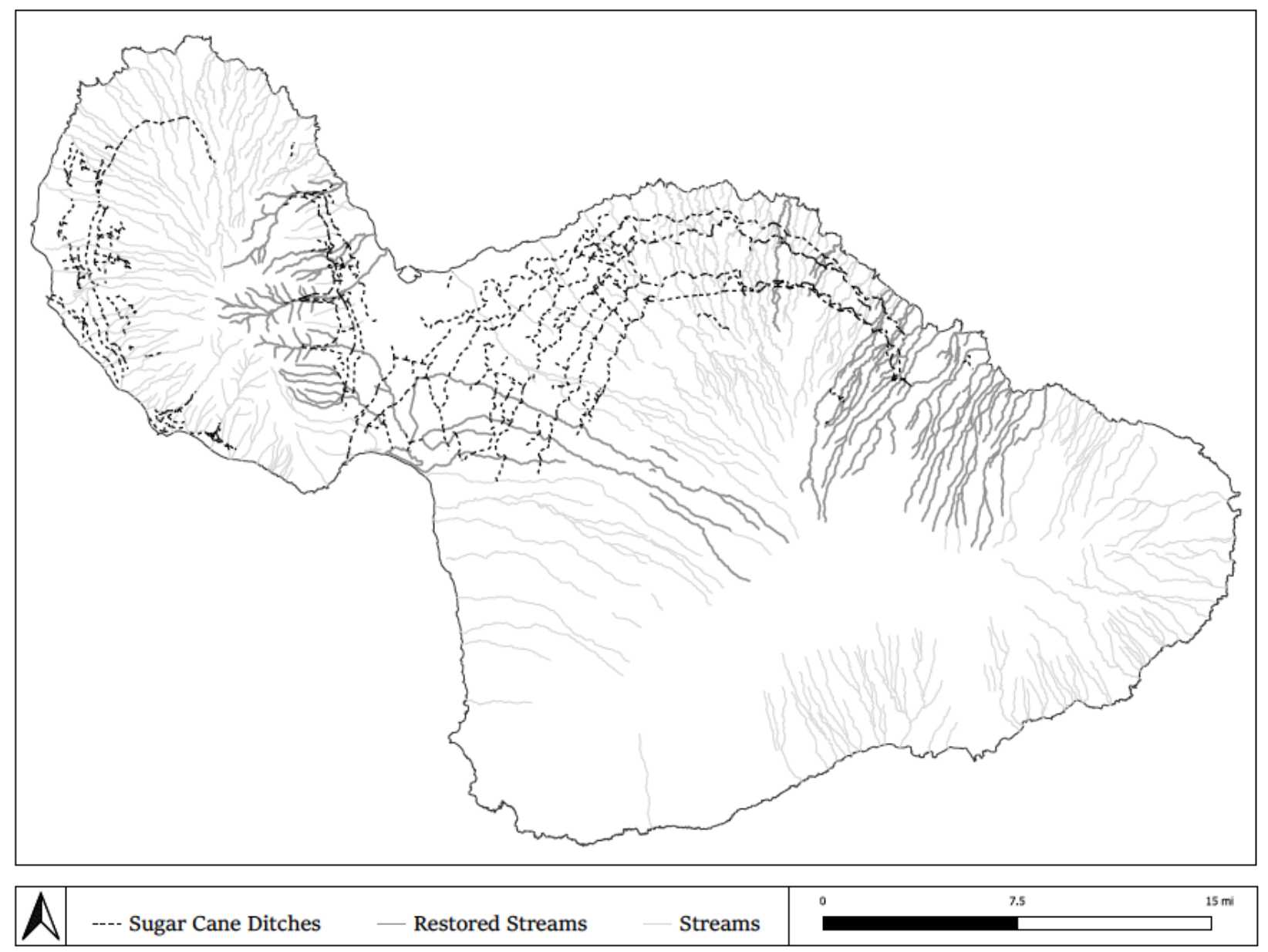

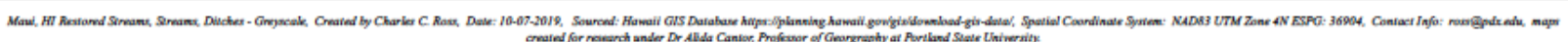

\subsection{Case 1: Nā Wai 'Ehā}

Central Maui's freshwater system is known as Nā Wai 'Ehā, "The Four Great Streams” (Figure

2; includes highlighted streams discharging into the north and south sides of Central Maui's

isthmus). The Waihe‘e River, Waiehu Stream, Wailuku River, and Waikapū Stream collectively hold significant Hawaiian cultural and ecological value. Together, the four ahuриа ${ }^{6} a$ containing the Four Great Streams historically represented the largest kalo growing region in Hawai'i, with over 4,000 lo'i kalo (taro fields) under cultivation, as well as the political, ritual, and population center of Maui (Hui o Nā Wai 'Ehā 2019). 
The Wailuku Sugar Company, established in 1862, diverted the streams for sugar plantation agriculture for over a century to the point where they no longer reached the ocean. The diversions diminished the Nā Wai 'Ehā streams and prevented them from flowing mauka to makai (from mountain to ocean). The overall diminishment of water impacted groundwater recharge, aquatic habitat, and traditional Hawaiian wetland kalo cultivation life (Gingerich and Wolff, 2005; Oki et al., 2010). In particular, the cessation of mauka to makai flow held cultural and symbolic impacts for Native Hawaiian water users (as well as impacting the life cycle of $o^{6} o p u$ - Hawaiian goby — and other aquatic organisms that migrate between freshwater and the ocean). Although the diverters of the Nā Wai 'Ehā streams, the Wailuku Sugar Company, cut their last crop of sugar in 1988, they continued to divert water to sell to other sugar producers such as the Hawaiian Commercial and Sugar Company (HC\&S). In 2005 the company reinvented itself as the Wailuku Water Company, diverting water to housing developments on former sugar plantation lands. As a community and environmental advocate described in an interview, longstanding structural power inequities made it difficult for community groups to push back on these practices:

“They [Wailuku Water Company] sold... Nā Wai 'Ehā water. They had these large customers. And they sold land and then stripped the water rights. This may be illegal. None of our people pushed on this because they weren't big land owners. These are brazen companies." 
Around 2003, the national environmental law organization Earthjustice began meeting with Native Hawaiian and non-Native residents concerned with stream health. In 2004, two community groups (the newly-formed Hui o Nā Wai 'Ehā and Maui Tomorrow, jointly represented by Earthjustice) petitioned the Water Commission to restore water to the four streams, arguing that Nā Wai 'Ehā represented an ecological and cultural public trust resource protected under the state's constitution. This launched a long legal battle to protect the streams of Nā Wai 'Ehā. In 2008, Nā Wai 'Ehā was designated as a Surface Water Management Area (the first such designation in Hawai'i), giving the Water Commission power to regulate use of surface water in the area through permits. In 2009, the Hearing Officer (an official designated as the lead on a Contested Case before the Water Commission) proposed instream flow standards (e.g., requirements for minimum quantities of water that must remain in a given stream at any given point) for the four streams (Table 2). However, in 2010 the Water Commission designated far less water to instream flows-notably, even less water than sugar producer HC\&S had requested (Sproat, 2014)—despite a strongly dissenting opinion from the Hearing Officer.

Table 2: Water allocation decisions for Nā Wai 'Ehā streams (mgd = million gallons per day)

\begin{tabular}{|l|l|l|l|l|l|}
\hline Decision/year & \multicolumn{4}{|c|}{ Amount of streamflow restored (or diverted) } \\
\hline & Waikapū & Wailuku & Waiehu & Waihe $\boldsymbol{e}^{\text {Total }}$ & To3.2 \\
\hline $\begin{array}{l}\text { Comparison: 2003 water } \\
\text { diversions by Wailuku } \\
\text { Water Company }\end{array}$ & & & & & $\begin{array}{l}(63)^{*} \\
\text { mgd }\end{array}$ \\
\hline $\begin{array}{l}\text { Hearing Officer instream } \\
\text { flow recommendation } \\
(2009)\end{array}$ & $4 \mathrm{mgd}$ & $13 \mathrm{mgd}$ & $3.5 \mathrm{mgd}$ & $14 \mathrm{mgd}$ & $34.5 \mathrm{mgd}$ \\
\hline $\begin{array}{l}\text { Water Commission } \\
\text { instream flow decision } \\
(2010)\end{array}$ & $0 \mathrm{mgd}$ & $0 \mathrm{mgd}$ & $2.5 \mathrm{mgd}$ & $10 \mathrm{mgd}$ & $12.5 \mathrm{mgd}$ \\
\hline $\begin{array}{l}\text { Mediated Agreement } \\
\text { instream flow allocation } \\
(2014)\end{array}$ & $2.9 \mathrm{mgd}$ & $10 \mathrm{mgd}$ & $2.5 \mathrm{mgd}$ & $10 \mathrm{mgd}$ & $25.4 \mathrm{mgd}$ \\
\hline
\end{tabular}




\begin{tabular}{|l|l|l|l|l|l|}
\hline Adjustments since 2014 & & & $\begin{array}{l}14 \mathrm{mgd} \\
(\mathrm{Jan} 2019)\end{array}$ & $29.4 \mathrm{mgd}$ \\
\hline
\end{tabular}

*According to a 2003 white paper by Wailuku Water Company. Precise numbers on individual stream diversions were not reported.

Hui o Nā Wai 'Ehā and Maui Tomorrow appealed to the Supreme Court, arguing forcefully that the Water Commission had violated its public trust duties in only allocating water to two streams, leaving the remaining two of the four streams dry. A Native Hawaiian community advocate noted the cultural importance of restoring all four streams:

“You know, Nā Wai 'Ehā means the four great waters. 'Ehā means four. It wasn't Nā Wai 'Elua, which means two, it wasn't Nā Wai 'Ekolu which means the three waters, it's the four waters."

In 2012 the Hawai'i Supreme Court heard the case and ruled in favor of the community groups. The Supreme Court found that the Water Commission's 2010 water allocation decisions had failed to comply with the state's duty to protect the public trust-which included protection of traditional and customary rights as well as ecological protection. This represented a significant victory for Native Hawaiian advocates who saw the integrity of mauka to makai streamflow as an important aspect of traditional and customary rights, and who held that cultural and ecological values were inextricable from one another. The Native Hawaiian community advocate quoted above described: 
"We're not here for benefiting one person, one business, one organization. Whether you're for the environment or not, it doesn't matter. We're here for the streams, and their protection, and to ensure connectivity of mauka to makai streamflow, and the traditional customary rights that go along with that."

The Supreme Court decision represented a major landmark in recognizing the integrated socioecological significance of the four streams. After new instream flows were agreed upon in 2014, for the first time in over a century, all four waters of Nā Wai 'Ehā finally flowed from mauka to makai.

\subsection{Case 2: East Maui}

In East Maui, a separate but related legal battle for water has also resulted in significant stream restoration (Figure 2; includes streams discharging into the eastern side of Maui). While some aspects of the process were similar, restoring streamflow in East Maui was a longer and more complex process than in Nā Wai 'Ehā because the stream system itself is more extensive and complex.

From the 1880 s to the 1980s, East Maui's streams were diverted by Hawaiian Commercial and Sugar Company (HC\&S), a subsidiary of Alexander and Baldwin (A\&B), for sugar production on around 40,000 acres of land in Maui's central isthmus, by far the largest sugar operation on Maui. For decades, East Maui Irrigation Company (part of A\&B) was granted long-term licenses to divert water from public and private lands in East Maui to the commercial sugar fields of central Maui. While the water diversions facilitated agriculture in central Maui and provided 
some groundwater recharge in this area, they also negatively impacted dozens of streams throughout East Maui, causing wetland kalo cultivation in East Maui to decline significantly (Miike, 2004; Wilcox, 1997). However, in the 1980s-90s, as Hawai'i’s sugar industry waned and the State of Hawai' $i$ adopted the State Water Code, A\&B's water permits came under scrutiny. Yet, given longstanding structural power arrangements, it took several more decades for actual water allocations to shift.

Together, East Maui community and environmental interests associated with Maui Tomorrow and kalo farmers represented by the Native Hawaiian Legal Corporation (NHLC) identified a set of streams that held particular cultural and ecological significance. In 2001, the coalition requested a contested case hearing to establish minimum instream flow standards for 27 of East Maui's many diverted streams (Figure 2; the 27 streams are highlighted streams discharging to Maui's northeastern coast). ${ }^{\text {ii }}$ As a Native Hawaiian attorney described, the case held deep cultural and historical roots, particularly for Native Hawaiians whose families had lost their ability to grow kalo as a result of the water diversions:

"On the East end, [water diversions] significantly impacted the way of life... today the descendants of those people that were impacted have taken up that struggle, and those are our clients. So you start to gain the perspective that this case isn't about us, it's about ultimately obtaining some form of justice for the people that were heavily impacted by the scam that was going on during their time. Their way of life was just disregarded. That's why it became a personal thing for me." 
Throughout the long legal process, $\mathrm{A} \& \mathrm{~B}$ continued to receive annual permits for water diversion. A few streams received limited water in 2007 and 2008 based on other Water Commission decisions (Table 3). The coalition of kalo farmers and environmentalists argued it was insufficient, but were denied a contested case hearing for many years. In 2012 the Intermediate Court of Appeals ruled the kalo farmers had a right to a hearing before the Water Commission, and the contested case hearing on minimum flow standards for the 27 streams—initially petitioned for in 2001—finally began in December 2014 (“CCH-MA13-01").

Table 3: Water allocation decisions for East Maui streams ( $m g d=$ million gallons per day)

\begin{tabular}{|c|c|c|}
\hline Decision/year & $\begin{array}{l}\text { Total amount of water } \\
\text { restored (or diverted) }\end{array}$ & Number of streams included \\
\hline $\begin{array}{l}\text { Comparison: Typical East } \\
\text { Maui water diversions by } \\
\text { Alexander \& Baldwin } \\
\text { (before end of sugar } \\
\text { cultivation in 2016) }\end{array}$ & (Over $160 \mathrm{mgd})$ & Over 100 streams \\
\hline 2007 & $6 \mathrm{mgd}$ & 1 stream \\
\hline $\begin{array}{l}\text { Water Commission } \\
\text { decision (2008) }\end{array}$ & $10.5 \mathrm{mgd}$ & 8 streams \\
\hline $\begin{array}{l}\text { Hearing Officer } \\
\text { recommendation (2016) }\end{array}$ & $18 \mathrm{mgd}$ & 27 streams \\
\hline $\begin{array}{l}\text { Water Commission } \\
\text { decision (2018) }\end{array}$ & $\begin{array}{l}\text { Varies (full flows in } 10 \\
\text { streams) }\end{array}$ & $\begin{array}{l}27 \text { streams, including full restoration } \\
\text { of } 10 \text { streams for kalo and at least } \\
90 \% \text { flow in } 7 \text { streams for habitat }\end{array}$ \\
\hline
\end{tabular}

Compared to the four relatively accessible streams of Nā Wai ‘Ehā, East Maui’s dozens of streams and hundreds of remote diversion points represented a more complex landscape, as a government agency staff member described:

"In East Maui, it was really overwhelming. We have 350 registered diversions in East Maui. The system is really complicated, it's really remote, and there's really not much 
information regarding actually how much water was available throughout the system. So how can you make a decision on how much water to leave in the stream if you don't know how much water is there to begin with?"

In 2016, the landscape of power over water shifted dramatically: HC\&S closed its doors after harvesting its last sugar crop on Maui. This political-economic shift finally translated into a political-ecological shift, as the last economic case for preserving the sugar industry's water rights crumbled. In the contested case hearing, the company repeatedly argued that any stream restoration would result in hundreds of lost jobs. With sugar production shuttered, this argument was suddenly invalid. As a Water Commission member described: "It's a real opportunity because sugar is a very thirsty crop and we're in this interim period where we're not growing sugar anymore."

In light of the changed political-economic landscape, the Water Commission Hearing Officer recommended restoring significantly more water to the 27 petitioned streams, determining that the company could pump groundwater from its own wells for its much-reduced operations. In summer 2018, the Water Commission announced final instream flow standards for East Maui, which included full restoration of 10 streams and at least $90 \%$ flow in 7 additional streams (Table 3). Here, the changed economic landscape had a profound impact on the political discourse, and in turn, on socioecological outcomes. Although the Water Commission had hesitated to restore streams when HC\&S was active, once sugar production had ceased, the Commission framed its decision to restore all 27 streams as a move toward meeting the 
responsibilities of the public trust: the Commission described their decision as one that would "align instream flow standards with our public trust responsibilities."

The decision was viewed as a victory for those who had been fighting for stream restoration for decades. The case had gone on for long enough that elder members of the original group of petitioners had died. A legal advocate noted, "That was the worst thing about this case, is that we never got to show them that we did it." The East Maui case is now completed, although advocates noted that enforcement and monitoring is still necessary to ensure instream flow standards are adhered to in practice.

\section{Analysis and discussion}

In this section, we analyze the cases described above and discuss the broader context of the public trust doctrine in Hawai' $i$. We first discuss the public trust as a hybrid, place-based, and evolving legal principle, then critically examine the processes through which the public trust is put into practice.

\subsection{The public trust as place-based and hybrid}

We conceptualize Hawai 'i's public trust doctrine as not only a plural legal doctrine with multiple roots (see: Robinson and Graham, 2018), but also as a hybrid in the sense that nature-society geographers and Indigenous scholars understand the term (e.g. Whatmore, 2002; TallBear, 2017). As a Native Hawaiian attorney explains in the quote below, the Hawaiian understanding of the public trust is drawn not only from the revised 1978 Hawai'i State Constitution, but also from a broader cultural approach that treats the public trust as a holistic "paradigm" for resource 
management (Sproat and Tuteur, 2018). Unlike in the Western United States-which the informant mentions as a comparison - the public trust in Hawai' $\mathrm{i}$ is about more than adjudicating use rights, since water is understood as a spiritual and relational entity with deep ties to traditional and customary practices across time and space.

“Well, [water] wasn't a commodity, you know. It was something that was the very essence of life, and protected. And it was connected to Kāne, who is the person who gives life. So it's not owned, no one owns water. And that's where, in Hawai'i at least, when you start talking about the public trust doctrine, it stems from Hawaiian tradition and custom. It's not necessarily born of the Western way of thinking of the public trust. It's more of... ok, that's the closest thing we can think of in Western terms to what Hawaiians were dealing with, so let's say it's the public trust. It's not necessarily the same thing as in the Western United States. It's based upon how water is treated by our ancestors."

Because the public trust can be traced through Native Hawaiian laws and systems of resource management as well as Western law, the principle carries unique strength in Hawai' $i$. As another lawyer interviewed put it, the public trust "just has a different meaning in Hawai “i." An interviewee involved in water and land management explained:

"Hawai' $\mathrm{i}$ is further along in understanding that indigeneity has to be a key part of land conservation. The public trust in Hawai'i does not just come from Roman law, it has 
Indigenous roots as well. The public trust is more spiritually and morally grounded here, and the public trust in Hawai'i comes from Indigenous practices and law."

Arguably, Western ideas of the public trust also have moral and spiritual groundings, albeit in different moral and religious traditions. Yet as the quotations from the interviewees above demonstrate, the grounding of the Hawaiian public trust specifically in Hawaiian moral and spiritual groundings is significant. This understanding of contemporary Hawaiian state law as intimately related to Native Hawaiian law and tradition came through clearly in our interactions with our informants. Among Native Hawaiians involved in the water rights cases, we observed many interviewees simultaneously establishing their rights to water by calling on Native Hawaiian mythology while also reciting specific state statutes or pulling out and reading from their well-worn copies of primers on state water law.

The Hawaiian public trust can be understood not only as a plural/hybrid legal system involving multiple human legal systems, but also as a nature-society hybrid. Hawai'i's water systems have been described as hybrid networks of human and more-than-human elements including "ruling hierarchies, social identity, labor structures, conflict resolution institutions, environmental abuse, sacred crops, and export agriculture" (Berry, 2014, 81). Contemporary Hawaiian water laws can also be considered hybrid in this sense. Because of Hawaiian water management's deep roots in Native Hawaiian law and tradition, contemporary Hawaiian law does not distinguish between the human and nonhuman environment (Sproat, 2011) in the same way that Western legal tradition does (see, e.g., Delaney, 2003; Martin et al., 2018). 
Hawai'i's public trust differs from that of other US states, such as California, where the public trust has been primarily used to protect nonhuman environments (Cantor, 2016). The State of Hawai' $i$, in contrast, has taken a broad reading of the public trust that includes protection of cultural practices. This conceptualization of natureculture (e.g. Haraway 2003) is a unique product of Hawaiian history and culture. The Hawaiian State Constitution, for example, gives explicit protection to "traditional and customary rights" related to water (section 12.7), including "all rights customarily and traditionally exercised for subsistence, cultural and religious purposes" by "descendants of native Hawaiians who inhabited the Hawaiian Islands prior to 1778." By including subsistence and cultural practices as part of the public trust doctrine, rather than limiting the doctrine to nonhuman environments, Hawai'i's version of the public trust incorporates a broader socionatural understanding. Restoration of streams in Nā Wai 'Ehā and East Maui has more than 'environmental' benefits: it has facilitated partial restoration of lo' $\mathrm{i}$ kalo, which provides farmers and their communities with a nutritious complex carbohydrate staple that was a principal food source for early Hawaiians. Growing kalo also connects Native Hawaiians to a plant that according to a creation legend is the elder sibling of humanity (Cho et al., 2007). Interviewees emphasized the inextricability of nature and culture in Hawaiian law and resource management. An attorney explained, "It's inescapable in a place like Hawai'i where the environment and culture are one." Another Hawaiian attorney put it, simply, "We see ourselves as part of the environment." Sproat proposes the idea of the "public trust as paradigm"- that is, the public trust is more than a singular law, it is a powerful concept that permeates all dimensions of resource use (Sproat and Tuteur, 2018). 
The public trust is also an example of how legal knowledge and practices travel from place to place, evolving and hybridizing along the way (e.g., Kedar, 2003, 2014; Mawani and Hussin, 2014). Echoing literature on policy mobilities (McCann and Ward, 2012; Temenos and McCann, 2013), legal communities in multiple states and countries adopt each others' best practices, allowing legal approaches and ideas to travel from one place to another. The use of the public trust in Maui demonstrates not only how law is rooted in place, but also how law travels and hybridizes as unique place-based factors are absorbed. Interviewees described how attorneys picked from the "best" aspects of the public trust doctrine from cases across the Hawaiian Islands and continental United States, infusing them with aspects unique to Hawai' $i$ and Maui more specifically. Attorneys involved in other Hawaiian cases, including Waiāhole, were informed by the successes of California's 1983 Mono Lake case, in which the California Supreme Court ruled that California had an obligation to protect the ecological and aesthetic public trust values of Mono Lake (Hart, 1996). ${ }^{\text {iii }}$ The principle resonated with Hawaiian water lawyers, who made a conscious decision to utilize the public trust in their own efforts. As one lawyer described when asked why the public trust was leveraged in Hawaiian water rights cases, "The public trust is used here because we use it." That is, there was nothing inevitable about the use of the public trust: instead, its use represented a conscious choice to deploy the principle, inspired by other successful examples. As another environmental attorney described:

"In Hawai' $i$, I think we have the most robust public trust of anywhere in the nation... Waiāhole was a one-stop shop, in a sense, of all the best principles of public trust law around states, and it relied heavily on Mono Lake. But it took Mono Lake a couple of steps forward, I thought, even in Hawaiian law, to create this burden-shifting aspect, of 
the default being in favor of the public trust. And so diverters, especially for commercial purposes, have the burden to justify their diversions in light of the principles upheld by the public trust. So that's key."

Ideas, best practices, and case studies involving concepts like the public trust and legal personhood for nature continue to circulate internationally amongst a diverse international community of legal and Indigenous scholars focused on socioenvironmental law and governance, including Hawaiian legal scholars such as Kapua'ala Sproat (Martin et al., 2018). Legal ideas thus travel through networks of scholars and practitioners, hybridizing through place-specific implementation processes.

To summarize, the Hawaiian public trust doctrine is a plural legal system with roots in multiple legal systems and sets of norms (Beamer, 2014). The concept of the public trust is both rooted in Hawaiian law and principles regarding resource management as well as in Western traditions, and has also evolved through its travels. Hawai 'i's public trust is also a socionatural hybrid in that it incorporates both cultural and environmental aspects, instead of treating nature and culture as separate. In Hawai' $i$, the public trust has both cultural and environmental relevance, which stands in contrast to other places where the public trust has been applied more exclusively to (non-human) ecological protection (e.g., Cantor, 2016). Hawai'i's plural water law system incorporates principles of nature-society hybridity in ways that are rooted in the distinctive geography and history of Hawai' $i$. 


\subsection{Enacting the public trust: Balance and power}

Balancing multiple interests, including those of protection and development of water resources, involves the negotiation of different interests and values. However, from a political ecology perspective, such negotiations around interests and values are deeply infused with power and political-economic relationships. In the case of Hawai'i, the sugar industry's longstanding influence on the state's political and economic landscape has translated into domination over water resource use, and challenging this domination has been extremely difficult despite the existence of legal tools like the public trust doctrine.

As described in Section 4.2, Hawai'i's Water Commission plays a key role in defining the public good and balancing needs of competing public interests - a difficult task complicated by longstanding historical power imbalances that characterize the region's political economy. Critics note that since its conception in 1987, the Water Commission has always contained representatives with backgrounds in plantation agriculture, while Native Hawaiian and environmental interests have been systematically under-represented (Ho'okano, 2014). For example, a statutory requirement states that at least one member of the Water Commission needs to hold "substantial experience or expertise in traditional Hawaiian water resource management techniques and in traditional Hawaiian riparian usage” (Hawai 'i Revised Statutes $§ 174 C-7(b)$ ). But critics argue this requirement been historically ignored (Ho'okano, 2014), and even when the requirement has been observed, a single member can be easily overruled by industry interests. Through these structural factors, representational injustice has translated into distributional injustice (see, e.g., Zwarteveen and Boelens, 2014) as the Water Commission, designed to 
protect public interests in water, has in practice served to protect status quo and industry interests. As a Native Hawaiian community advocate explained in an interview:

“The Water Commission has had the worst track record... almost every vote that they've done in regards to stream flow has been overturned by the Hawai'i Supreme Court. They have a terrible track record, and that's because a lot of the people that have been on the Water Commission are former or current employees of [industrial agriculture].”

In our interviews, the term 'balance' in relation to water management generated strong reactions from many interviewees. An environmental attorney explained:

“That word [balance] gives me hives!... It's never been balanced, right, because they've been taking it all for a century plus. So it's more than ironic when you have diverters or their front people or shills saying we need balance or whatever, when they have all the water, or historically they've taken all the water."

Yet, not all institutions have been equally co-opted by structural power inequalities. Importantly, under the leadership of several Chief Justices committed to public and Indigenous rights, the Hawaiian Supreme Court has demonstrated willingness to push back on industry's hold on political economic power (Sproat, 2010). The Court has upheld the public trust and Native Hawaiian rights more broadly even in the face of opposition, and has ensured that the public interest remains strong in these interpretations of 'balance' (Sproat, 2010). As the Court explains in the Waiāhole case, “Any balancing between public and private purposes must begin with a 
presumption in favor of public use, access, and enjoyment" (Supreme Court of Hawai'i, 2000). The attorney quoted above offered the following explanation:

"The fundamental problem of balance is just, it's code for you can do whatever you want. Just as long as you say that word balance. But the public trust requires more. It sets some presumptions, it sets up burdens of proof and things like that. It's like a sort of balance, but with priorities."

Additionally, the structure of the Water Commission may not always remain that way, particularly as the dominance of sugar wanes. Although the Water Commission has historically been dominated by plantation agricultural interests, the individuals making up the Commission do change over time, which opens up the potential to introduce fresh priorities and perhaps to find new interpretations of 'balance.' For example, in January 2019, Hawai'i appointed a new Deputy Director, Kaleo Manuel, to lead the Commission on Water Resources Management. Upon his appointment, Manuel emphasized the principle of kuleana, a Hawaiian concept of responsibility and stewardship that implies care and respect. In a formal press release, Manuel stated: "Ola i ka wai-water is life. As a public trust resource, it is our collective kuleana to be responsible stewards of water for current and future generations." (Department of Land and Natural Resources, 2019). Such an appointment may represent a new chapter for the Water Commission and its mission of protecting water as a public trust resource.

At the same time, a political ecological perspective emphasizes that the persistence of historical injustices, structural inequalities, and unequal power distribution in legal geographies should not 
be underemphasized (Orzeck and Hae, 2019). As our discussion of balance and power within hybrid legal systems illustrates, hybrids are not necessarily equal, fifty-fifty blends of multiple legal traditions that co-exist peacefully. Structural power, political economy, and historical inequalities create an unequal playing field in which unequal socioecological arrangements persist despite the existence of a blended legal system that formally recognizes Native Hawaiian rights.

To summarize, in Maui, thanks to the decades of dedication on the part of community activists and their lawyers, streams are now flowing undiverted from mauka to makai for the first time in over a century. Aquatic life is returning rapidly to streams, and many more kalo farmers are able to grow their crops once again. The public trust has provided a powerful mechanism to secure water for cultural and ecological needs. At the same time, the public trust has frequently been disregarded by water managers. Despite the strength of Hawai'i's public trust in principle, decisions upholding the public trust have required significant effort to enact in practice. The recent decisions described here have been the exception, rather than the rule, and they come at a unique moment—at the end of commercial sugar production — where claims on private commercial use of water are (at least temporarily) weakened, although battles over Maui's water continue as new actors enter and make claims on water resources. ${ }^{\text {iv }}$ In this way, while the public trust theoretically contains the power to oppose commercial interests, the question of whether the doctrine is robust enough to routinely oppose the need to "balance" economic interests in the future remains an open one.

\section{Conclusions}


In this paper, we have drawn together concepts from legal geography and political ecology to examine water rights in Maui. In the cases examined here, community and environmental advocates successfully leveraged formal legal processes to challenge the entrenched sugar industry's claims to water, wai, which holds indescribable ecological and cultural significance in Hawaiian tradition. Political ecology contributes an analysis of the power dynamics involved in environmental conflicts and contestations over resources such as water, while legal geography helps unpack the co-constitutive relationships between law and place as legal principles such as the public trust are interpreted and enacted. Political ecology also contributes empirical field methods that can add place-specific context when combined with the textual analysis methods of legal studies. Bringing these two fields together contributes a stronger understanding of the context-specific, place-based, power-laden relationships between legal processes and socioenvironmental change.

In particular, we have used the cases of water allocation in Maui to illustrate several main points. First, we demonstrate that the concepts of legal pluralism and socionatural hybridity can be used in tandem to strengthen one another. Hawai 'i's public trust doctrine is an example of legal pluralism in which multiple legal traditions with different roots overlap and intersect. Hawai'i's public trust doctrine is also an example of hybridity in that it recognizes the importance of both nature and culture in relation to water. Cultural claims to water resources were just as important as ecological claims; these claims intersected and strengthened the overall case for stream restoration. We also show how legal ideas are hybridized as they actively travel from place to place through networks of legal practitioners and scholars, evolving and adapting along the way. 
Second, our examination of balance and power, rooted in political ecology's approach of examining power dynamics in socioenvironmental conflicts, illuminates tensions between structure and agency. On the one hand, written law is interpreted and enacted by people; the makeup of organizations such as Hawai'i's Water Commission changes over time as new individuals join and bring different priorities to the Commission. Yet, historical structural and historical inequalities tied to ongoing marginalization of Native Hawaiian people and their resource claims persist. The power imbalances described here make clear that legal pluralism does not necessarily result in peaceful reconciliation of multiple traditions.

Broadly, our study contributes to a growing body of work combining political ecology and legal geographic theory and methodology to examine the interactions between formalized legal and policy processes and socioenvironmental contestations and change. Together, these approaches help develop specific, empirical, place-based analyses of the complex relationships between legal and socioenvironmental change. Geographers are uniquely positioned to understand legal processes as plural, place-specific hybrids including human and more-than-human elements and differentiated power relations. 


\section{References}

Andrews, E., McCarthy, J., 2014. Scale, shale, and the state: political ecologies and legal geographies of shale gas development in Pennsylvania. J. Environ. Stud. Sci. 4, 7-16.

Barad, K., 2007. Meeting the universe halfway: Quantum physics and the entanglement of matter and meaning. duke university Press.

Bartel, R., 2018. Place-speaking: Attending to the relational, material and governance messages of Silent Spring. Geogr. J. 184, 64-74.

Beamer, K., 2014. No mākou ka mana: Liberating the nation. Kamehameha Publishing.

Bennett, L., Layard, A., 2015. Legal geography: Becoming spatial detectives. Geogr. Compass 9 , 406-422.

Berry, K.A., 2014. Actor-network theory and traditional cultural properties: Exploring irrigation as a hybrid network in 19th century Hawai'i. Hum. Geogr. 7, 73-87.

Berry, K.A., 2006. Changing Narratives of Water Control in Hawai'i, in: Tvedt, T., Oestigaard, T. (Eds.), A History of Water, Volume 3: The World of Water. pp. 38-48.

Berry, K.A., Jackson, S., 2018. The making of white water citizens in Australia and the Western United States: Racialization as a transnational project of irrigation governance. Ann. Am. Assoc. Geogr. 108, 1354-1369.

Birkenholtz, T., 2009. Irrigated landscapes, produced scarcity, and adaptive social institutions in Rajasthan, India. Ann. Assoc. Am. Geogr. 99, 118-137.

Blumm, M.C., Wood, M.C., 2013. The public trust doctrine in environmental and natural resources law. Carolina Academic Press Durham, North Carolina, USA.

Boelens, R., Hoogesteger, J., Swyngedouw, E., Vos, J., Wester, P., 2016. Hydrosocial territories: a political ecology perspective.

Boelens, R., Vos, J., 2014. Legal pluralism, hydraulic property creation and sustainability: the materialized nature of water rights in user-managed systems. Curr. Opin. Environ. Sustain. $11,55-62$.

Braverman, I., 2014. Who's afraid of methodology? Advocating a methodological turn in legal geography. Advocating a Methodol. Turn Leg. Geogr. 120-141.

Braverman, I., Blomley, N.K., Delaney, D., Kedar, A., 2014. The expanding spaces of law : a timely legal geography. Stanford Law Books.

Brown, K.M., Flemsæter, F., Rønningen, K., 2019. More-than-human geographies of property: Moving towards spatial justice with response-ability. Geoforum 99, 54-62.

Cano Pecharroman, L., 2018. Rights of nature: rivers that can stand in Court. Resources 7, 13.

Cantor, A., 2016. The public trust doctrine and critical legal geographies of water in California. Geoforum 72, 49-57.

Cantor, A., Stoddard, E., Rocheleau, D., Brewer, J., Roth, R., Birkenholtz, T., Foo, K., Nirmal, P., 2018. Putting Rooted Networks Into Practice. ACME An Int. J. Crit. Geogr. 14, 958987.

Charpleix, L., 2018. The Whanganui River as Te Awa Tupua: Place-based law in a legally pluralistic society. Geogr. J. 184, 19-30.

Cho, J.J., Yamakawa, R.A., Hollyer, J., 2007. Hawaiian Kalo, Past and Future. Cooperative Extension Service, College of Tropical Agriculture and Human Resources, University of Hawai'i at Mānoa, Honolulu.

Conway, D.M., 2008. Indigenizing intellectual property law: customary law, legal pluralism, and the protection of indigenous peoples' rights, identity, and resources. Tex. Wesley. L. Rev. 
$15,207$.

Cooper, G., Daws, G., 1990. Land and power in Hawaii: The democratic years. University of Hawaii Press.

Curran, D., 2019. Indigenous Processes of Consent: Repoliticizing Water Governance through Legal Pluralism. Water 11, 571.

Delaney, D., 2017. Legal geography III. Prog. Hum. Geogr. 41, 667-675.

Delaney, D., 2003. Law and nature. Cambridge University Press.

Department of Land and Natural Resources, 2019. New Water Deputy Appointed at DLNR.

Fisher, S., 2015. Hawaiian culture and its foundation in sustainability, in: Chirico, J., Farely, G. (Eds.), Thinking like an Island: Navigating a Sustainable Future in Hawai'i. University of Hawai'i Press.

French, A., 2019. Webs and flows: socionatural networks and the matter of nature at Peru's Lake Parón. Ann. Am. Assoc. Geogr. 109, 142-160.

Giambelluca, T.W., Chen, Q., Frazier, A.G., Price, J.P., Chen, Y.-L., Chu, P.-S., Eischeid, J.K., Delparte, D.M., 2013. Online rainfall atlas of Hawai 'i. Bull. Am. Meteorol. Soc. 94, $313-$ 316.

Gillespie, J., 2018. Wetland conservation and legal layering: Managing Cambodia's great lake. Geogr. J. 184, 31-40.

Gillespie, J., 2016. Catch 22: Wetlands protection and fishing for survival. Geogr. Res. 54, 336347.

Gillespie, J., 2011. Legal pluralism and world heritage management at Angkor, Cambodia. Asia Pac. J. Envtl. L. 14, 1.

Gingerich, S.B., Wolff, R.H., 2005. Effects of surface-water diversions on habitat availability for native macrofauna, Northeast Maui, Hawaii. US Department of the Interior, US Geological Survey.

Griffiths, J., 1986. What is legal pluralism? J. Leg. Plur. Unoff. law 18, 1-55.

Haraway, D., 1991. Simians, cyborgs, and women: The reinvention of nature. Routledge.

Haraway, D.J., 2003. The companion species manifesto: Dogs, people, and significant otherness. Prickly Paradigm Press Chicago.

Hart, J., 1996. Storm over Mono: the Mono Lake battle and the California water future. Univ of California Press.

Hartwig, D.L., Jackson, S., Osborne, N., 2018. Recognition of Barkandji Water Rights in Australian Settler-Colonial Water Regimes. Resour. .

Harvey, D., 2003. The new imperialism. OUP Oxford.

Ho'okano, P., 2014. Aia i Hea ka Wai a Kāne? (Where Indeed is the Water of Kāne?):

Examining the East Maui Water Battle, in: Goodyear-Kaopua, N., Hussey, I., Wright, E.K. (Eds.), A Nation Rising: Hawaiian Movements for Life, Land, and Sovereignty.

Howitt, R., Suchet-Pearson, S., 2006. Rethinking the building blocks: ontological pluralism and the idea of 'management.' Geogr. Ann. Ser. B, Hum. Geogr. 88, 323-335.

Hui o Na Wai 'Eha, 2019. Hui o Na Wai 'Eha: Historical and Cultural Background [WWW Document].

Jackson, S., 2018. Water and Indigenous rights: Mechanisms and pathways of recognition, representation, and redistribution. Wiley Interdiscip. Rev. Water 5, e1314.

Jeffrey, A., Jakala, M., 2014. The hybrid legal geographies of a war crimes court. Ann. Assoc. Am. Geogr. 104, 652-667.

Jepson, W., 2012. Claiming Space, Claiming Water: Contested Legal Geographies of Water in 
South Texas. Ann. Assoc. Am. Geogr. 102, 614-631.

Johnson, A.G., Engott, J.A., Bassiouni, M., 2014. Spatially distributed groundwater recharge estimated using a waterbudget model for the island of Maui, Hawai 'i, 1978-2007. US Geol. Surv. Sci. Investig. Rep 5168, 53.

Kay, K., 2016. Breaking the bundle of rights: Conservation easements and the legal geographies of individuating nature. Environ. Plan. A Econ. Sp. 48, 504-522.

Kedar, A., 2003. On the legal geography of ethnocratic settler states: Notes towards a research agenda. Curr. Leg. issues 5, 401-441.

Kedar, A.S., 2014. Expanding legal geographies: A call for a critical comparative approach, in: Braverman, I., Blomley, N.K., Delaney, D., Kedar, A.S. (Eds.), The Expanding Spaces of Law: A Timely Legal Geography. Stanford University Press, p. 95.

Latour, B., 1993. We have never been modern. Harvard University Press.

Lave, R., 2015. Political ecology and actor-network theory. Routledge Handb. Polit. Ecol. 1st ed. Routlegde.

Levin, P., 2015. Searching for Sustainable Agriculture in Hawai'i, in: Chirico, J., Farley, G. (Eds.), Thinking like an Island: Navigating a Sustainable Future in Hawai'i. University of Hawai'i Press, pp. 46-78.

Linton, J., Budds, J., 2014. The hydrosocial cycle: Defining and mobilizing a relationaldialectical approach to water. Geoforum 57, 170-180.

MacLennan, C.A., 2014. Sovereign sugar: industry and environment in Hawaii. University of Hawaii Press.

Martin, B., Te Aho, L., Humphries-Kil, M., 2018. ResponsAbility: Law and Governance for Living Well with the Earth. Routledge.

Mawani, R., Hussin, I., 2014. The travels of law: Indian Ocean itineraries. Law Hist. Rev. 32, 733-747.

McCann, E., Ward, K., 2012. Assembling urbanism: following policies and 'studying through'the sites and situations of policy making. Environ. Plan. A 44, 42-51.

Meehan, K.M., 2014. Tool-power: Water infrastructure as wellsprings of state power. Geoforum 57, 215-224.

Merry, S.E., 1988. Legal pluralism. Law Soc'y Rev. 22, 869.

Miike, L.H., 2008. The Waiāhole Ditch: a case study of the management and regulation of water resources in Hawai'i, in: Coastal Watershed Management. WIT Press Southampton, UK, pp. 369-401.

Miike, L.H., 2004. Water and the Law in Hawaii. University of Hawai'i Press.

Mintz, S.W., 1986. Sweetness and power: The place of sugar in modern history. Penguin.

O'Donnell, T., 2019. Coastal management and the political-legal geographies of climate change adaptation in Australia. Ocean Coast. Manag. 175, 127-135.

Oki, D.S., Wolff, R.H., Perreault, J.A., 2010. Effects of surface-water diversion on streamflow, recharge, physical habitat, and temperature, Nā Wai 'Ehā, Maui, Hawai 'i. US Geol. Surv. Sci. Invest. Rep 5011, 154.

Orzeck, R., Hae, L., 2019. Restructuring legal geography. Prog. Hum. Geogr.

Quastel, N., 2017. Pashukanis at Mount Polley: Law, eco-social relations and commodity forms. Geoforum 81, 45-54.

Rajagopal, B., 2005. The role of law in counter-hegemonic globalization and global legal pluralism: lessons from the Narmada Valley struggle in India. Leiden J. Int. Law 18, 345387. 
Randeria, S., 2006. Entangled histories: Civil society, caste solidarities and legal pluralism in post-colonial India. Civ. Soc. Berlin Perspect. 2, 213.

Robbins, P., 2011. Political ecology: A critical introduction. John Wiley \& Sons.

Robertson, S., 2015. Natives making space: The Softwood Lumber dispute and the legal geographies of Indigenous property rights. Geoforum 61, 138-147.

Robinson, D.F., Graham, N., 2018. Legal pluralisms, justice and spatial conflicts: New directions in legal geography. Geogr. J. 184, 3-7.

Rocheleau, D., Roth, R., 2007. Rooted networks, relational webs and powers of connection: Rethinking human and political ecologies. Geoforum 3, 433-437.

Roth, D., Boelens, R., Zwarteveen, M., 2015. Property, legal pluralism, and water rights: the critical analysis of water governance and the politics of recognizing "local" rights. J. Leg. Plur. Unoff. Law 47, 456-475.

Salgo, M., Gillespie, J., 2018. Cracking the Code: a legal geography and political ecological perspective on vegetation clearing regulations. Aust. Geogr. 49, 483-496.

Sax, J.L., 1970. The public trust doctrine in natural resource law: Effective judicial intervention. Mich. Law Rev. 68, 471-566.

Sneddon, C., 2003. Reconfiguring scale and power: the Khong-Chi-Mun project in northeast Thailand. Environ. Plan. A 35, 2229-2250.

Sproat, D., 2010. Where Justice Flows Like Water: The Moon Court's Role in Illuminating Hawai'i Water Law. U. Haw. L. Rev. 33, 537.

Sproat, K., 2014. A Question of Wai: Seeking Justice through Law for Hawai'i's Streams and Communities, in: Goodyear-Ka'opua, N., Hussey, I., Kahunawaika'ala Wright, E. (Eds.), A Nation Rising: Hawaiian Movements for Life, Land, and Sovereignty.

Sproat, K., 2011. Wai through Kanawai: Water for Hawai'i's Streams and Justice for Hawaiian Communities. Marq. L. Rev. 95, 127.

Sproat, K., 2009. Ola i Ka Wai: A Legal Primer for Water Use and Management in Hawai'i. Ka Huli Ao Center for Excellence in Native Hawaiian Law.

Sproat, K., Tuteur, M., 2018. The power and potential of the public trust: insight from Hawai'i's water battles and triumphs, in: Martin, B., Te Aho, L., Humphries-Kil, M. (Eds.), ResponsAbility: Law and Governance for Living Well with the Earth. Routledge.

Supreme Court of Hawai'i, 2000. IN RE: the WATER USE PERMIT APPLICATIONS, Petitions for Interim Instream Flow Standard Amendments, and Petitions for Water Reservations for the Waiāhole Ditch Combined Contested Case Hearing. No. 21309.

Swyngedouw, E., 2009. The Political Economy and Political Ecology of the Hydro-Social Cycle. J. Contemp. Water Res. Educ. 142, 56-60.

Swyngedouw, E., 1999. Modernity and hybridity: nature, regeneracionismo, and the production of the Spanish waterscape, 1890-1930. Ann. Assoc. Am. Geogr. 89, 443-465.

Sylva, S., 2007. Indigenizing Water Law in the 21st Century: Na Moku Aupuni O Ko'Olau Hui, a Native Hawaiian Case Study. Cornell J. Law Public Policy 16, 563.

TallBear, K., 2017. Beyond the life/not life binary: a feminist-indigenous reading of cryopreservation, interspecies thinking and the new materialisms. Cryopolitics Frozen life a melting world 179-202.

Tamanaha, B.Z., 2008. Understanding legal pluralism: past to present, local to global. Sydney L. Rev. 30, 375.

Tamanaha, B.Z., 1993. The folly of the'social scientific'concept of legal pluralism. J. Law Soc. 20, $192-217$. 
Temenos, C., McCann, E., 2013. Geographies of policy mobilities. Geogr. Compass 7, 344-357. Turton, D.J., 2015. Unconventional Gas in A ustralia: Towards a Legal Geography. Geogr. Res. $53,53-67$.

Vaughan, M.B., Thompson, B., Ayers, A.L., 2017. Pāwehe Ke Kai a 'o Hā 'ena: creating state law based on customary indigenous norms of coastal management. Soc. Nat. Resour. 30, $31-46$.

von Benda-Beckmann, F., 2002. Who's afraid of legal pluralism? J. Leg. Plur. Unoff. Law 34, 37-82.

Vos, H. de, Boelens, R., Bustamante, R., 2006. Formal law and local water control in the Andean region: A fiercely contested field. Water Resour. Dev. 22, 37-48.

Whatmore, S., 2002. Hybrid geographies: Natures cultures spaces. Sage.

Whatmore, S., 1999. Hybrid geographies: rethinking the 'human'in human geography, in: Massey, D., Allen, J., Sarre, P. (Eds.), Human Geography Today. Polity PRess, pp. 22-40.

Wilcox, C., 1997. Sugar water: Hawaii's plantation ditches. University of Hawaii Press.

Winter, K., Beamer, K., Vaughan, M., Friedlander, A., Kido, M., Whitehead, A., Akutagawa, M., Kurashima, N., Lucas, M., Nyberg, B., 2018. The Moku System: Managing biocultural resources for abundance within social-ecological regions in Hawai'i. Sustainability 10, 3554.

Wood, M.C., 2014. Nature's trust: Environmental law for a new ecological age. Cambridge University Press.

Yilmaz, I., 2016. Muslim laws, politics and society in modern nation states: Dynamic legal pluralisms in England, Turkey and Pakistan. Routledge.

Zwarteveen, M., Roth, D., Boelens, R., 2005. Water rights and legal pluralism, in: Roth, D., Boelens, R., Zwarteveen, M. (Eds.), Liquid Relations: Contested Water Rights and Legal Complexity. pp. 254-268.

Zwarteveen, M.Z., Boelens, R., 2014. Defining, researching and struggling for water justice: some conceptual building blocks for research and action. Water Int. 39, 143-158.

\section{Endnotes}

\footnotetext{
${ }^{\mathrm{i}}$ In the United States, each state has its own state court system with broad jurisdiction to handle many issues. The federal court system of the United States handles a limited range of cases related to the U.S. Constitution and federal law. The public trust doctrine is primarily implemented at the state level, and thus different states interpret the doctrine differently. Many water-related issues, including water rights, are also handled at the state level. However, a few important federal laws_-such as the federal Endangered Species Act and the federal Clean Water Act-are also relevant to water management.

ii The remaining streams were either smaller; did not support kalo cultivation or other cultural practices; and/or held less habitat value. Diversion on the remaining streams was still allowed to continue for off-stream domestic and agricultural purposes. Even after Alexander and Baldwin ceased sugar production, East Maui Irrigation Company continued to divert limited amounts of water for non-sugar operations including livestock pastures, feedstock crops, and experimental biofuel crops. Environmental advocates have criticized these ongoing diversions as unnecessary and opaque.

iii Law's travels can be multidirectional, as well. For example, the advances of the public trust doctrine under Hawai'i's Waiāhole decision (itself inspired by California's use of the public trust) may circle back to California. The Waiāhole decision was unique in framing groundwater and surface water resources as interconnected; the decision clarified that groundwater resources are eligible for protection under the public trust doctrine in Hawai' $i$. Recently, a California decision around surface water depletion related to groundwater extraction introduced new precedent for including groundwater under California's public trust as well.
} 
${ }^{\text {iv }}$ In December 2018, Alexander and Baldwin announced a real estate deal in which 41,000 acres of former sugar land were sold to Mahi Pono LLC, a joint farming venture of a California-based agricultural company and a Canadian public pension fund. The Mahi Pono operation will require significant quantities of water, although exact amounts are still under negotiation and the outcomes are unknown at the time of writing this article. 